\title{
Ribavirin as a First Treatment Approach for Hepatitis E Virus Infection in Transplant Recipient Patients
}

\author{
Antonio Rivero-Juarez ${ }^{1, *}$, Nicolau Vallejo ${ }^{2}$, Pedro Lopez-Lopez ${ }^{1}\left(\mathbb{D}\right.$, Ana Isabel Díaz-Mareque ${ }^{3}$, \\ Mario Frias ${ }^{1}$, Aldara Vallejo ${ }^{4}$, Javier Caballero-Gómez ${ }^{1,5}$, María Rodríguez-Velasco ${ }^{4}$, \\ Esther Molina ${ }^{2}$ and Antonio Aguilera ${ }^{4}$ \\ 1 Infectious Diseases Unit, Clinical Virology and Zoonoses research group, Hospital Universitario Reina Sofía \\ de Córdoba, Instituto Maimonides de Investigación Biomédica de Córdoba (IMIBIC), Universidad de \\ Córdoba, 14006 Cordoba, Spain; lopezlopezpedro07@gmail.com (P.L.-L.); \\ mariofriascasas@hotmail.com (M.F.); javiercaballero15@gmail.com (J.C.-G.) \\ 2 Digestive Unit, Complexo Hospitalario Universitario de Santiago, 15705 Santiago de Compostela, Spain; \\ nicolau.vallejo.senra@sergas.es (N.V.); esther.molina.perez@sergas.es (E.M.) \\ 3 Nephrology Unit, Complexo Hospitalario Universitario de Santiago, 15705 Santiago de Compostela, Spain; \\ ana.isabel.diaz.mareque@sergas.es \\ 4 Microbiology Unit, Complexo Hospitalario Universitario de Santiago, University of Santiago de Compostela, \\ 15705 Santiago de Compostela, Spain; laramva@hotmail.com (A.V.); \\ maria.rodriguez.velasco@sergas.es (M.R.-V.); antonio.aguilera.guirao@sergas.es (A.A.) \\ 5 Animal Health Department, University of Cordoba-Agrifood Excellence International Campus (ceiA3), \\ 15705 Cordoba, Spain \\ * Correspondence: arjvet@gmail.com or antonio.rivero@imibic.org; Tel.: +(34)-957213806; \\ Fax: +(34)-947011885
}

Received: 22 October 2019; Accepted: 23 December 2019; Published: 26 December 2019

\begin{abstract}
The hepatitis E virus (HEV) is the major cause of acute hepatitis of viral origin worldwide. Despite its usual course as an asymptomatic self-limited hepatitis, there are highly susceptible populations, such as those with underlying immunosuppression, which could develop chronic hepatitis. In this situation, implementation of therapy is mandatory in the sense to facilitate viral clearance. Currently, there are no specific drugs approved for HEV infection, but ribavirin (RBV), the drug of choice, is used for off-label treatment. Here, we present two cases of chronic HEV infection in transplant patients, reviewing and discussing the therapeutic approach available in the literature. The use of RBV for the treatment of an HEV infection in organ transplant patients seems to be effective. The recommendation of 12 weeks of therapy is adequate in terms of efficacy. Nevertheless, there are important issues that urgently need to be assessed, such as optimal duration of therapy and drug dosage.
\end{abstract}

Keywords: HEV; treatment; zoonoses; ribavirin; transplant

\section{Introduction}

Hepatitis E virus (HEV) is an RNA virus belonging to the Orthohepevirus genus that can infect a large number of hosts, including mammals (genera A, C and D) and birds (genus B) [1,2]. Viruses included in the Orthohepeviridae A family, genotypes 1 to 4 , are a major cause of acute hepatitis worldwide [3]. The seroprevalence strongly varies between countries, become higher than $40 \%$ in Asia [3]. Moreover, genotypes 1 and 2 produce large outbreaks of acute hepatitis in low to middle income countries in Asia and Africa, and are associated with the consumption of contaminated water [4], whereas genotypes 3 and 4 have a global distribution producing sporadic cases, which are mainly documented in countries from the Americas and Europe, and are associated with the consumption of 
raw or undercooked food of animal origin [5,6]. Despite these two epidemiologically well-differentiated types of HEV that usually present as asymptomatic or self-limited acute hepatitis, clinical presentations and outcomes can vary depending on the population affected [7]. Genotypes 1 and 2 have been shown to have the worst prognosis, including a fatal outcome, in patients with underlying liver cirrhosis and pregnant women [8,9], while genotypes 3 and 4 can cause extrahepatic manifestations (highlighting those affecting central and peripheral nervous systems) and, under immunosuppression conditions, could involve chronic hepatitis $[10,11]$.

Chronic HEV infection is defined as viral persistence in peripheral blood for more than three months [12,13]. The susceptible population comprises populations of patients with underlying immunosuppression, such as patients who are transplant recipients, patients who are HIV infected (with a total CD4 ${ }^{+}$cell count lower than 200 cells $/ \mathrm{mL}$ ) and patients treated with rituximab or with antitumoral necrosis factor drugs $[12,13]$. Once a chronic HEV infection is diagnosed, the therapeutic approach first consists of a reduction in the immunosuppression (if possible) and, in case of failure of self-resolution, implementation of therapy. Currently, there are no specific drugs approved for HEV infection, but ribavirin (RBV), the drug of choice, is used for off-label treatment. Studies investigating the safety and efficacy of the treatment of chronic HEV with RBV are limited to reports of medium to small cohorts and case reports, and clinical trials are lacking. Here, we present two cases of chronic HEV infection in transplant patients, reviewing and discussing the evidences for their first therapeutic approach.

\section{Description of Cases}

\subsection{Case 1}

A 65-year-old male who received a liver transplant in 2010 was admitted in February 2019 due to an elevated level of transaminases. The patient presented negative HCV antibodies, $\mathrm{sHbAg}$ and anti HBc, as well as HCV RNA and HBV DNA. In March, the patient was diagnosed with an HEV infection with detectable ant-HEV IgG and IgM antibodies and detectable HEV RNA in the serum. HEV antibodies were tested by indirective chemiluminescence immunoassay (CLIA) (Hepatitis E Virclia IgG Monotest and Hepatitis E Virclia IgM Monotest), following the manufacturer's instructions. For HEV RNA determination, we used LightMix Modular Hepatitis E Virus (TIB MOLBIOL, Berlin, Germany). This assay has a detection limit set up at 10 genome equivalent copies or less per reaction (in vitro transcribed RNA). Total RNA extraction was performed from $200 \mu \mathrm{L}$ of serum, using the automated MagNA Pure Compact RNA Isolation kit (Roche Diagnostics Corporation, Indianapolis, IN, USA), following the manufacturer's instructions. The purified RNA was eluted in a total elution volume of $50 \mu \mathrm{L}$. The patient was receiving immunosuppressive therapy everolimus $(0.5 \mathrm{mg}$ every $12 \mathrm{~h}$ ) in combination with mycophenolate mofetil (500 mg every $12 \mathrm{~h}$ ). For phylogenetic analysis, a nested RT-PCR was performed, targeting the ORF2 region (structural proteins), using primers HEV_5920S (5'-CAAGGㅂTGGCGYTCKGGTTGAGAC-3') and HEV_6425A (5'-CAAGGHTGGCGYYTCKGTTGAGAC-3') in the first round and HEV_5930S

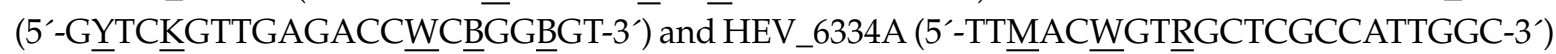
in the second round. The second amplification product of $467 \mathrm{bp}$ was sequenced using the BigDe Terminator Cycle Sequencing Ready Reaction Kit on an ABI PRISM 3100 Genetic Analyzer (Applied Biosystems, Foster City, CA, USA). SnapGene software (Version 3.1; GSL Bio-tech, snapgene.com) was used for sequence analysis. The consensus sequence was obtained using SeqMan Software SeqMan NGen ${ }^{\circledR}$ Version 12.0 (DNASTAR. Madison, WI, USA). Subtype assignment and phylogenetic analyses were performed using the HEVnet genotyping tool (https://www.rivm.nl/mpf/typingtool/hev/) and confirmed by BLAST. Genotyping of the viral strain was consistent with the genotype $3 f$. The patient reported, as risk factors for acquiring HEV, consumption of domestically prepared pork and wild boar. Twelve weeks after diagnosis of HEV infection, the patient remained with a detectable HEV viral load, been diagnosed with chronic infection. At this point, RBV was initiated at a dose of $200 \mathrm{mg}$ every $8 \mathrm{~h}$ 
for 12 weeks, following clinical guidelines. During therapy, the patient experienced normalization of transaminases and did not report side effects associated with the medication. At the end of therapy, the HEV viral load was negative in the plasma and feces. The patient continues to have a negative viral load in the plasma and feces 24 weeks after completion of the therapy and has attained sustained virological response (SVR).

\subsection{Case 2}

A 35-year-old female had a kidney transplant in 2013. After transplantation, the patient experienced acute dysfunction of the graft and drug-related leucopenia was solved. From May 2018, the patient received prednisone ( $5 \mathrm{mg} /$ day), tacrolimus ( $1.5 \mathrm{mg} /$ day) and sirolimus ( $1 \mathrm{mg} / \mathrm{day})$ as immunosuppressive therapy. The patient presented with an elevated level of transaminases in May 2018 and was suspected to have a drug-induced liver injury due to paracetamol, hypolipemiant therapy and contraceptive medication. She was negative for $\mathrm{HCV}$ antibodies, $\mathrm{sHbAg}$ and anti $\mathrm{HBc}$, but positive for anti-HBs (48 mIU/mL). Viral load for HCV and HBV were also undetectable. Nevertheless, after drug interruption or switching, the elevated level of transaminases persisted. In March 2019, the patient was transferred to the hepatology unit and was diagnosed with an HEV infection, showing positive levels of anti-HEV IgG and IgM antibodies. HEV RNA was detected in the plasma and was determined to be genotype 3f. HEV RNA remains to be detectable 12 weeks later, confirming chronic HEV infection. As in the first case, RBV was initiated at a dose of $200 \mathrm{mg}$ every $8 \mathrm{~h}$ for 12 weeks. During the therapy, the patient experienced normalization of transaminases and did not report side effects associated with the medication. At the end of therapy, the HEV viral load was negative in the plasma and feces, and the patient continues to have a negative viral load 24 weeks after the completion of therapy.

\subsection{Ethics}

This study was designed and performed according to the Helsinki Declaration. Patients provided permission to publish clinical data anonymously.

\section{Discussion}

After the diagnosis of a chronic HEV infection in organ transplant patients, clinical guidelines propose the first approach to reduce immunosuppression is to facilitate a self-limiting infection. A large series of 56 chronic HEV-infected transplant patients were evaluated, and the treatment strategy was to reduce the dose of the immunosuppressive medications [11]. Eighteen (32.1\%) patients experienced viral clearance, with a median of 19.5 (10-106) months. Similarly, in a study in which 15 solid organ transplant patients were retrospectively identified with a chronic HEV infection, three experienced spontaneous viral clearance after the reduction in immunosuppressive therapy [14]. The resolving infection occurred between 3 and 30 months after initiating the reduction. In another cohort that included six chronically infected patients in whom the decreased dose was specifically aimed at facilitating HEV clearance, the infection was resolved in three patients (50\%) [15]. In another study, in which five heart transplant recipients were diagnosed with chronic HEV infection, one patient experienced viral resolution after dose reduction of tacrolimus [16]. Thus, these relatively large cohorts show that a high proportion of patients could benefit from a dose reduction of immunosuppressive medications. Nevertheless, this result should be taken with caution. First, other studies or case reports showed a failure of viral clearance after immunosuppressive dose reduction [17-21]. Second, the elapsed time between the initiation of immunosuppression reduction and the time of self-resolution could be as high as or more than 1 year [11,14]. Finally, this reduction may be avoided in allogeneic hematopoietic stem cell transplant (alloHSCT) recipients, since a recent study found a strong association between immunosuppressive dose reduction and risk of mortality [22]. In this study, 2 out of 7 alloHSCT patients with a chronic HEV infection, in whom immunosuppressive drugs were reduced, had died due to the fulminant graft versus host disease. The identification of factors associated with failure/experience 
self-viral resolution can be helpful in terms of clinical decision making. In this sense, the use of tacrolimus rather than cyclosporin A has been identified as an independent predictive factor for the development of chronic HEV infection [11]; therefore, switching medications could be considered in these patients to facilitate HEV infection resolution. Nevertheless, cyclosporin A has been shown to have a higher risk of acute rejection than tacrolimus. For these reasons, reducing or changing immunosuppressive medications should be considered individually in the risk-benefit equation. For these reasons, the first therapeutic approach for inducing viral clearance in our cases was not the reduction of the immunosuppression therapy, but the uptake of RBV therapy.

Despite the fact that the use of RBV for HEV infection should be considered as an experimental therapy due to its off-label use, a large number of cases reported in the literature use this compound, and RBV is recommended in clinical guidelines for HEV management in the general population, specifically in transplant-recipient individuals (Table 1) [12,13].

All these recommendations are based on a series of cases and case reports, summarized in Table 2. Because there are no clinical trials evaluating the proper course of RBV for the treatment of an HEV infection, the duration and dosage vary among studies (Table 2). Because of the disparity between studies, a meta-analysis cannot be conducted. However, considering the population reported as a whole, a total of 374 transplant patients have been treated with RBV and 276 of these patients have attained SVR, with a clearance rate of $73.7 \%$ (Table 2). When analyzing the treatment response by transplant organ, all populations included seemed to have a similar successful treatment outcome (kidney, liver, heart, lung and alloHSCT). Nevertheless, these data were cautiously reviewed because treatment lengths and drug dosages were variable. In this sense, clinical guidelines recommend a program therapy duration of 12 weeks using RBV at the initiation with a weight-adjusted dose or a dose adjusted on the basis of the estimated glomerular filtration rate $[12,13,23]$. Following these recommendations, a total of 176 transplant patients have been reported, and 129 of these patients have achieved SVR (73.2\%) [11,24-33]. Therefore, this recommendation seems to be highly effective for the treatment of HEV infection in transplant recipients infected by genotype $3 \mathrm{HEV}$. Consequently, we decided to initiate this program in both cases following this recommendation. HEV was successfully cleared, showing a high safety and efficacy of this strategy in this setting. Despite that, a clinical trial evaluating the proper duration and dosage of RBV in transplant patients is mandatory.

However, despite the reported efficacy of RBV, there are several patients in who RBV is contraindicated, including pregnancy or those with a creatinine clearance lower than $50 \mathrm{~mL} / \mathrm{min}$ [59]. Consequently, the development of new drugs is mandatory for the management of HEV infection. Therapeutic alternatives have been evaluated in vitro and in vivo. Sofosbuvir (SOF), a drug targeting the HCV NS5B polymerase, has shown to have an inhibitory effect on HEV replication [60]. Furthermore, the combination of SOF and RBV have demonstrated a cumulative effect for inhibiting HEV viral replication, suggesting a potential alternative approach. Nevertheless, its application in a clinical setting is inconclusive. While several studies have reported a successful treatment outcome of the combination of SOF + RBV in transplant recipients with chronic HEV infection, including one case of kidney and other of alloHSCT [61-63], others have not demonstrated its efficacy in this population $[45,64,65]$. Due to that, SOF seems to not add antiviral activity to RBV in vivo. On the other hand, the use of SOF monotherapy in those patients who are not eligible for RBV use has demonstrated a lack of efficacy [66]. Furthermore, the lack of efficacy also has been reported in the second-line treatment approach in transplant-recipient patients [67]. Consequently, the use of SOF is not recommended for the therapy of HEV infection. Other drugs have demonstrated antiviral activity against HEV in vitro, such Deptropine or Ciprofloxacin $[68,69]$. Nevertheless, currently there are no evidences in vivo and further investigation in this sense are needed. 
Table 1. Treatment recommendations for chronic hepatitis E virus infection according to clinical guidelines.

\begin{tabular}{|c|c|c|c|}
\hline Recommendation & EASL & GeHEP/SEIMC & BTS \\
\hline Reference & [13] & [12] & [23] \\
\hline Drug & RBV & RBV & RBV \\
\hline Treatment duration & 12 weeks & 12 weeks & 12 weeks \\
\hline Dosage & Not specified & Weight-adjusted & Not specified \\
\hline Monitoring HEV RNA during therapy & At week 12 & At weeks 4 and 12 & At weeks $1,4,8$ and 12 \\
\hline $\begin{array}{l}\text { Increase therapy duration after } \\
\text { completion of } 12 \text { weeks }\end{array}$ & $\begin{array}{c}\text { Up to } 24 \text { weeks if detectable viral load at week } \\
12 \text { in plasma/serum or feces }\end{array}$ & $\begin{array}{c}\text { Up to } 24 \text { weeks if detectable viral load at week } \\
12 \text { in plasma/serum or feces }\end{array}$ & $\begin{array}{l}\text { Continue until } 2 \text { stools }>1 \text { month apart are } \\
\text { both negative or continue for } 24 \text { weeks }\end{array}$ \\
\hline Retreatment & $\begin{array}{l}\text { RBV for } 24 \text { weeks. If failure, consider treatment } \\
\text { with Peg-IFN alpha for } 12 \text { weeks * }\end{array}$ & $\begin{array}{l}\text { RBV for } 24 \text { weeks. If failure, consider treatment } \\
\text { with Peg-IFN alpha for } 12 \text { weeks * }\end{array}$ & $\begin{array}{l}\text { RBV for } 24 \text { weeks. If failure, consider treatment } \\
\text { with Peg-IFN alpha for } 12 \text { weeks * }\end{array}$ \\
\hline
\end{tabular}

Table 2. Efficacy of ribavirin monotherapy as first treatment for hepatitis E virus genotype 3 infection in adult transplant recipient patients.

\begin{tabular}{|c|c|c|c|c|c|c|c|c|}
\hline Reference & $n$ & Transplant & Country & Genotype & $\begin{array}{c}\text { Duration, Median } \\
\text { (Range) or Mean (SD) }\end{array}$ & Dosage & SVR (\%) * & Note \\
\hline \multicolumn{9}{|c|}{ Studies on kidney transplant patients } \\
\hline Present study & 1 & Kidney & Spain & 3 & 12 weeks & $600 \mathrm{mg} /$ day & $1(100)$ & \\
\hline [24] & 2 & Kidney & Japan & 3 & 12 weeks & $600 \mathrm{mg} /$ day & $2(100)$ & \\
\hline [25] & 16 & Kidney & Germany & 3 & 12 weeks & $600 \mathrm{mg} /$ day $(200-800 \mathrm{mg})$ & $15(93.7)$ & $\begin{array}{l}\text { Patients started therapy within the } \\
\text { first } 2 \text { weeks after diagnosis of } \\
\text { HEV infection }\end{array}$ \\
\hline [26] & 1 & Kidney & France & 3 & 12 weeks & $1200 \mathrm{mg} /$ day & $1(100)$ & $\begin{array}{l}\text { Patient started therapy at the same } \\
\text { week of diagnosis due to acute } \\
\text { graft rejection }\end{array}$ \\
\hline [34] & 16 & Kidney & Germany & 3 & $15.2(11.6)$ & $\begin{array}{l}85.7 \mathrm{mg}(200 \mathrm{mg} \text {, thrice a week) } \\
\text { and } 1000 \mathrm{mg} / \text { day }\end{array}$ & $11(68.5)$ & \\
\hline [35] & 1 & Kidney & Argentina & 3 & 16 weeks & $1000 \mathrm{mg} /$ day & $1(100)$ & \\
\hline [36] & 1 & Kidney & France & 3 & 68 weeks & $10 \mathrm{mg} / \mathrm{kg}$ & $1(100)$ & \\
\hline
\end{tabular}


Table 2. Cont

\begin{tabular}{|c|c|c|c|c|c|c|c|c|}
\hline Reference & $n$ & Transplant & Country & Genotype & $\begin{array}{c}\text { Duration, Median } \\
\text { (Range) or Mean (SD) }\end{array}$ & Dosage & $\operatorname{SVR}(\%) *$ & Note \\
\hline [27] & 2 & Kidney & Spain & Unknown & 12 weeks & $600-800 \mathrm{mg} /$ day & $2(100)$ & \multirow{7}{*}{$\begin{array}{c}\text { Withdrew at week } 4 \text { due to severe } \\
\text { adverse events } \\
\text { Patient who did not achieve SVR } \\
\text { experienced viral relapse after } 2 \\
\text { months of therapy }\end{array}$} \\
\hline [37] & 1 & Kidney & $\begin{array}{l}\text { The } \\
\text { Netherlands }\end{array}$ & 3 & 16 weeks & $400-600 \mathrm{mg} /$ day & 0 & \\
\hline [14] & 4 & Kidney & Germany & 3 & 20 weeks & $600-1200 \mathrm{mg} /$ day & $4(100)$ & \\
\hline [11] & 6 & Kidney & France & 3 & 12 weeks & $800 \mathrm{mg} /$ day & $4(66.6)$ & \\
\hline [38] & 1 & $\begin{array}{c}\text { Kidney } \\
\text { pediatric }\end{array}$ & Germany & 3 & 12 weeks & $10 \mathrm{mg} / \mathrm{kg}$ & 0 & \\
\hline [18] & 4 & $\begin{array}{l}\text { Kidney } \\
\text { pediatric }\end{array}$ & Germany & 3 & 12 weeks & $\begin{array}{c}9.7 \mathrm{mg} / \mathrm{kg} \text { (range: } 3.6 \text { to } 15.4 \\
\mathrm{mg} / \mathrm{kg})\end{array}$ & $3(75)$ & \\
\hline [39] & 1 & Kidney-pancreas & France & 3 & 12 weeks & $12 \mathrm{mg} / \mathrm{kg}$ & $1(100)$ & \\
\hline \multicolumn{9}{|c|}{ Studies on liver transplant recipients } \\
\hline Present study & 1 & Liver & Spain & 3 & 12 weeks & $600 \mathrm{mg} /$ day & $1(100)$ & \multirow{10}{*}{$\begin{array}{c}\text { One death before completing } \\
\text { treatment }\end{array}$} \\
\hline [40] & 1 & Liver & Uruguay & 3 & 9 weeks & $1200 \mathrm{mg} /$ day & $1(100)$ & \\
\hline [41] & 4 & Liver & Portugal & 3 & 24 weeks & $800-1200 \mathrm{mg} /$ day & $4(100)$ & \\
\hline [20] & 1 & Liver & Japan & 3 & 20 weeks & $800 \mathrm{mg} /$ day & $1(100)$ & \\
\hline [42] & 1 & Liver & Japan & 3 & 20 weeks & $\begin{array}{l}200 \mathrm{mg} / \text { day and gradually } \\
\text { increased up to } 600 \mathrm{mg} / \text { dav }\end{array}$ & $1(100)$ & \\
\hline$[28]$ & 4 & Liver & Germany & 3 & 12 weeks & $600 \mathrm{mg} /$ day $(200-800)$ & $3(75)$ & \\
\hline [43] & 1 & Liver & Australia & 3 & 12 weeks & $200 \mathrm{mg} /$ day & $1(100)$ & \\
\hline [44] & 1 & Liver & Germany & 3 & 16 weeks & $600 \mathrm{mg} /$ day & $1(100)$ & \\
\hline [14] & 4 & Liver & Germany & 3 & 20 weeks & $600-1200 \mathrm{mg} /$ day & $3(75)$ & \\
\hline [21] & 1 & Liver pediatric & Germany & 3 & 24 weeks & $400 \mathrm{mg} /$ day & $1(100)$ & \\
\hline \multicolumn{9}{|c|}{ Studies on Heart transplant recipients } \\
\hline [45] & 1 & Heart & France & 3 & 12 weeks & $800 \mathrm{mg} /$ day & 0 & \multirow{6}{*}{$\begin{array}{l}\text { Patient deceased at the end of } \\
\text { therapy with detectable viral load }\end{array}$} \\
\hline$[46]$ & 1 & Heart & France & 3 & 10 weeks & $\begin{array}{l}200 \mathrm{mg} / \text { day and gradually } \\
\text { increased up to } 400 \mathrm{mg} / \text { day }\end{array}$ & 0 & \\
\hline [47] & 1 & Heart & Sweden & 3 & 36 weeks & $\begin{array}{l}800 \mathrm{mg} / \text { day for } 18 \text { weeks and } 1200 \\
\text { mg/day for } 18 \text { weeks }\end{array}$ & $1(100)$ & \\
\hline [16] & 4 & Heart & $\begin{array}{l}\text { The } \\
\text { Netherlands }\end{array}$ & 3 & $12-36$ weeks & $200-800 \mathrm{mg} /$ day & $3(75)$ & \\
\hline [48] & 4 & Heart & Germany & 3 & 20 weeks & $800 \mathrm{mg} /$ day & $3(75)$ & \\
\hline [49] & 1 & Heart & France & 3 & 12 weeks & $17 \mathrm{mg} / \mathrm{kg}$ & $1(100)$ & \\
\hline \multicolumn{9}{|c|}{ Studies on Lung transplant recipients } \\
\hline$[50]$ & 4 & Lung & Germany & 3 & 18 weeks & $400-800 \mathrm{mg} /$ day & $2(50)$ & $\begin{array}{l}\text { One patient died at week } 4 \text { of } \\
\text { therapy due to acute graft rejection }\end{array}$ \\
\hline
\end{tabular}


Table 2. Cont.

\begin{tabular}{|c|c|c|c|c|c|c|c|c|}
\hline Reference & $n$ & Transplant & Country & Genotype & $\begin{array}{c}\text { Duration, Median } \\
\text { (Range) or Mean (SD) }\end{array}$ & Dosage & $\operatorname{SVR}(\%) *$ & Note \\
\hline [51] & 2 & Lung & $\begin{array}{l}\text { The } \\
\text { Netherlands }\end{array}$ & 3 & 16 weeks & $400 \mathrm{mg} /$ day & $2(100)$ & $\begin{array}{l}\text { One patient showed detectable } \\
\text { HEV RNA in stools at evaluation } \\
\text { of SVR }\end{array}$ \\
\hline [14] & 3 & Lung & Germany & 3 & 20 weeks & 600-1200 mg/day & $2(66.6)$ & $\begin{array}{c}\text { One death before treatment } \\
\text { completion }\end{array}$ \\
\hline \multicolumn{9}{|c|}{ Studies on alloHSCT } \\
\hline [52] & 13 & alloHSCT & France & 3 & 12 weeks ( $3-49$ weeks) & $400-1000 \mathrm{mg} /$ day & $11(84.6)$ & $\begin{array}{l}\text { One death before treatment } \\
\text { completion }\end{array}$ \\
\hline [22] & 8 & alloHSCT & $\begin{array}{l}\text { France, } \\
\text { Germany, the } \\
\text { Netherlands } \\
\text { and Scotland }\end{array}$ & 3 & 12 weeks (1-32 weeks) & $10 \mathrm{mg} / \mathrm{kg}$ (range: 5 to $22 \mathrm{mg} / \mathrm{kg}$ ) & $7(87.5)$ & $\begin{array}{l}\text { Patients } 3,1 \text { and } 4 \text { received therapy } \\
\text { with viral shedding }<12,12-24, \\
\text { and }>24 \text { weeks, respectively }\end{array}$ \\
\hline \multicolumn{9}{|c|}{ Studies not reporting SVR per type of transplant } \\
\hline [29] & 48 & $\begin{array}{c}\text { Kidney }(n=29) \\
\text { Liver }(n=13) \\
\text { Heart }(n=3) \\
\text { Lung }(n=1) \\
\text { Kidney/Pancreas } \\
(n=2) \\
\text { Kidney }(n=5)\end{array}$ & France & 3 & 12 weeks & 600 mg/day (600-800 mg/day) & $38(79.1)$ & \\
\hline [30] & 8 & $\begin{array}{c}\text { Liver }(n=2) \\
\text { Bone marrow }(n \\
=1) \\
\text { Kidney }(n=45)\end{array}$ & Singapore & 3 & 12 weeks & 600 mg/day (400-800 mg/day) & $2(25)$ & $\begin{array}{l}\text { All kidney transplant recipients } \\
\text { fail to respond to therapy }\end{array}$ \\
\hline [53] & 63 & $\begin{array}{l}\text { Liver }(n=10) \\
\text { Heart }(n=5) \\
\text { Lung }(n=3)\end{array}$ & France & 3 & 12 weeks (12-72 weeks) & 600 mg/day (200-1200 mg/day) & $42(66.6)$ & $\begin{array}{l}40 \text { patients previously included in } \\
\text { Kamar et al. NEJM } 2014\end{array}$ \\
\hline [31] & 35 & $\begin{array}{c}\text { Kidney }(n=22) \\
\text { Liver }(n=8) \\
\text { Heart }(n=3) \\
\text { Lung }(n=1) \\
\text { Kidney/Pancreas } \\
(n=1)\end{array}$ & France & 3 & 12 weeks & 600 mg/day (200-1200 mg/day) & $22(62.8)$ & $\begin{array}{l}22 \text { patients previously included in } \\
\text { Kamar et al. NEJM } 2014\end{array}$ \\
\hline
\end{tabular}


Table 2. Cont.

\begin{tabular}{|c|c|c|c|c|c|c|c|c|}
\hline Reference & $n$ & Transplant & Country & Genotype & $\begin{array}{c}\text { Duration, Median } \\
\text { (Range) or Mean (SD) }\end{array}$ & Dosage & $\operatorname{SVR}(\%) *$ & Note \\
\hline [32] & 4 & $\begin{array}{c}\text { Liver }(n=1) \\
\text { Kidney }(n=2) \\
\text { Liver/Kidney }(n \\
=1)\end{array}$ & Spain & 3 & 12 weeks & $600-800 \mathrm{mg} /$ day & $3(75)$ & \\
\hline [33] & 24 & $\begin{array}{c}\text { Kidney }(n=16) \\
\text { Liver }(n=5) \\
\text { Heart }(\mathrm{n}=2) \\
\text { Lung }(n=1)\end{array}$ & France & 3 & 12 weeks & 600 mg/day (200-1200 mg/day) & $15(62.5)$ & \\
\hline [54] & 15 & $\begin{array}{l}\text { Not specified } \\
\text { Kidney }(n=37)\end{array}$ & Germany & 3 & Not specified & Not specified & $13(86.6)$ & \\
\hline [55] & 59 & $\begin{array}{c}\text { Liver }(n=10) \\
\text { Heart }(n=5) \\
\text { Lung }(n=2) \\
\text { Kidney/Pancreas } \\
(n=5)\end{array}$ & France & 3 & 12 weeks (4-72 weeks) & 600 mg/day (29-1200) & $46(77.9)$ & \\
\hline [56] & 41 & $\begin{array}{c}\text { Kidney }(n=26) \\
\text { Liver }(n=9) \\
\text { Heart }(n=3) \\
\text { Kidney/pancreas } \\
(n=1) \\
\text { Lung }(n=1) \\
\text { Liver } / \text { kidney }(n \\
=1)\end{array}$ & France & 3 & 12 weeks & $9.7 \mathrm{mg} / \mathrm{kg} /$ day $(2.7-16.3)$ & $25(61 \%)$ & \\
\hline \multicolumn{9}{|c|}{ Studies on transplant patients infected by HEV genotype different than 3} \\
\hline [19] & 1 & Kidney & China & 4 & 24 weeks & RBV (not specified) & 0 & \\
\hline [57] & 3 & Kidney & China & 4 & 12 weeks & RBV (800 mg/day) & $2(66.6)$ & \\
\hline [17] & 1 & Liver & Switzerland & 3ra & $\begin{array}{c}16 \text { weeks } \mathrm{RBV}+24 \text { weeks } \\
\mathrm{RBV} / \mathrm{SOF}+16 \text { weeks } \\
\mathrm{RBV}\end{array}$ & $\begin{array}{c}\text { RBV }(1129-3700 \mathrm{ng} / \mathrm{mL}) \text { and SOF } \\
(400 \mathrm{mg} / \text { day })\end{array}$ & 0 & \\
\hline [58] & 1 & Not specified & $\begin{array}{l}\text { Switzerland } \\
\text { Singapore }\end{array}$ & 3 ra & 12 weeks & RBV (not specified) & $1(100)$ & \\
\hline [30] & 1 & Liver & $\begin{array}{l}\text { (patient from } \\
\text { United Arab } \\
\text { Emirates) }\end{array}$ & 7 & 12 weeks & $600 \mathrm{mg} /$ day $(400-800 \mathrm{mg} /$ day $)$ & $1(100)$ & \\
\hline
\end{tabular}

Number of patients (n); standard deviation (SD); sustained virological response (SVR); milligram (mg); hepatitis E virus (HEV); allogenic hematopoietic stem cell transplantation (alloHSCT). * SVR was defined as undetectable HEV RNA in serum and stools 12 and/or 24 weeks after completing the therapy. 


\section{Conclusions}

In our experience, the use of RBV for the treatment of an HEV infection in organ transplant patients is effective, and the recommendation of 12 weeks of therapy being adequate in terms of efficacy. Nevertheless, there are important issues that urgently need to be assessed, such as the optimal duration of therapy and drug dosage of RBV, as well the development of new drugs with a high safety profile.

Author Contributions: Conceptualization, A.R.-J. and A.A.; methodology, A.R.-J. and A.A.; formal analysis, A.R.-J., P.L.-L. and A.A.; resources, N.V., A.I.D.-M., M.F., A.V., M.R.-V. and E.M.; data curation, M.F., P.L.-L., J.C.-G., A.R.-J., and A.A.; writing-original draft preparation, A.R.-J. and A.A.; writing-review and editing, A.R.-J. and A.A.; funding acquisition, A.R.-J. and A.A. All authors have read and agreed to the published version of the manuscript.

Funding: This work was supported by the Ministry of Economy and Competitiveness (RD12/0017/0012) integrated in the National R+D+i Plan and co-financed by the European Regional Development Fund, and the Health Research Fund from the Institute of Health Carlos III (ISCIII) (PI16/01297), and The SPANISH AIDS Research Network RD16/0025/0034, ISCIII-FEDER. A.R.-J. is the recipient of a Miguel Servet Research Contract by the Ministerio de Ciencia, Promoción y Universidades of Spain (CP18/00111). M.F. is the recipient of a Sara Borrell contract by the Ministerio de Ciencia, Promoción y Universidades of Spain (CD18/00091). J.C.-G. is supported by an FPU grant from the Spanish Ministry of Education, Culture and Sport (FPU17/01319). The funders did not play any role in the design, conclusions or interpretation of the study.

Conflicts of Interest: A.R.-J. received public funding for this research by Fundación para la investigación en Salud (FIS) of the Instituto de Salud Carlos III. Additionally, he received private research support by AbbVie y ViiV Healthcare. He received payment for consultation by Roche Diagnostics, Gilead, and Bristol Mier Squidd and payment for lectures, including service on speakers' bureaus from Bristol Mier Squidd, ViiV Healtcare, Janssen Cilag, MSD, Roche Diagnostics, AbbVie, and Gilead. Any of these companies have no role within the present manuscript. The rest of authors declare no conflicts of interest.

\section{References}

1. Forni, D.; Cagliani, R.; Clerici, M.; Sironi, M. Origin and dispersal of Hepatitis E virus. Emerg. Microbes Infect. 2018, 7, 11. [CrossRef] [PubMed]

2. Sun, P.; Lin, S.; He, S.; Zhou, E.M.; Zhao, Q. Avian Hepatitis E Virus: With the Trend of Genotypes and Host Expansion. Front. Microbiol. 2019, 10, 1696. [CrossRef] [PubMed]

3. World Health Organization. Global Hepatitis Report 2017. 2017. Available online: http://www.who.int/ hepatitis/publications/global-hepatitis-report2017/en/ (accessed on 10 October 2019).

4. World Health Organization. Waterborne Outbreaks of Hepatitis E: Recognition, Investigation and Control. 2014. Available online: https://www.who.int/hepatitis/publications/HepE-manual/en/ (accessed on 10 October 2019).

5. Faber, M.; Askar, M.; Stark, K. Case-control study on risk factors for acute hepatitis E in Germany, 2012 to 2014. Euro Surveill. 2018, 23. [CrossRef] [PubMed]

6. Suin, V.; Klamer, S.E.; Hutse, V.; Wautier, M.; Jacques, M.; Abady, M.; Lamoral, S.; Berburgh, V.; Thomas, I.; Brochier, B.; et al. Epidemiology and genotype 3 subtype dynamics of hepatitis E virus in Belgium, 2010 to 2017. Euro Surveill. 2019, 24. [CrossRef] [PubMed]

7. Hartl, J.; Wehmeyer, M.H.; Pischke, S. Acute Hepatitis E: Two Sides of the Same Coin. Viruses 2016, 8, 299. [CrossRef] [PubMed]

8. Kumar Acharya, S.; Kumar Sharma, P.; Singh, R.; Kumar Mohanty, S.; Madan, K.; Kumar Jha, J.; Kumar Panda, S. Hepatitis E virus (HEV) infection in patients with cirrhosis is associated with rapid decompensation and death. J. Hepatol. 2007, 46, 387-394. [CrossRef] [PubMed]

9. Khuroo, M.S.; Kamili, S.; Khuroo, M.S. Clinical course and duration of viremia in vertically transmitted hepatitis E virus (HEV) infection in babies born to HEV-infected mothers. J. Viral Hepat. 2009, 16, 519-523. [CrossRef]

10. Pischke, S.; Hartl, J.; Pas, S.D.; Lohse, A.W.; Jacobs, B.C.; Van der Eijk, A.A. Hepatitis E virus: Infection beyond the liver? J. Hepatol. 2017, 66, 1082-1095. [CrossRef]

11. Kamar, N.; Garrouste, C.; Haagsma, E.B.; Garrigue, V.; Pischke, S.; Chauvet, C.; Dumortier, J.; Cannesson, A.; Cassuto-Viguier, E.; Thervet, E.; et al. Factors associated with chronic hepatitis in patients with hepatitis E virus infection who have received solid organ transplants. Gastroenterology 2011, 140, 1481-1489. [CrossRef] 
12. Rivero-Juarez, A.; Aguilera, A.; Avellón, A.; García-Deltoro, M.; García, F.; Gortazar, C.; Granados, R.; Macías, J.; Merchante, N.; Oteo, J.A.; et al. Executive summary: Consensus Document of the Diagnosis, management, and prevention of infection with the hepatitis E virus: Study Group for Viral Hepatitis (GEHEP) of the Spanish Society of Infectious Diseases and Clinical Microbiology (SEIMC). Enferm. Infecc. Microbiol. Clin. 2018. [CrossRef]

13. European Association for the Study of the Liver. EASL Clinical Practice Guidelines on hepatitis E virus infection. J. Hepatol. 2018, 68, 1256-1271. [CrossRef] [PubMed]

14. Pischke, S.; Hardtke, S.; Bode, U.; Birkner, S.; Chatzikyrkou, C.; Kauffmann, W.; Bara, C.L.; Gottlieb, J.; Wenzel, J.; Manns, M.P.; et al. Ribavirin treatment of acute and chronic hepatitis E: A single-centre experience. Liver Int. 2013, 33, 722-726. [CrossRef] [PubMed]

15. Moal, V.; Legris, T.; Burtey, S.; Morange, S.; Purgus, R.; Dussol, B.; Garcia, S.; Motte, A.; Gérolami, R.; Berland, Y.; et al. Infection with hepatitis E virus in kidney transplant recipients in southeastern France. J. Med. Virol. 2013, 85, 462-471. [CrossRef] [PubMed]

16. Koning, L.; Pas, S.D.; de Man, R.A.; Balk, A.H.; de Knegt, R.J.; ten Kate, F.J.; Osterhaus, A.D.; van der Eijk, A.A. Clinical implications of chronic hepatitis E virus infection in heart transplant recipients. J. Heart Lung Transpl. 2013, 32, 78-85. [CrossRef]

17. Fraga, M.; Gouttenoire, J.; Sahli, R.; Chtioui, H.; Marcu, C.; Pascual, M.; Moradpour, D.; Vionnet, J. Sofosbuvir add-on to ribavirin for chronic hepatitis $\mathrm{E}$ in a cirrhotic liver transplant recipient: A case report. BMC Gastroenterol. 2019, 19, 76. [CrossRef]

18. Cordts, S.E.; Schneble, L.; Schnitzler, P.; Wenzel, J.J.; Vinke, T.; Rieger, S.; Fichtner, A.; Tönshoff, B.; Höcker, B. Prevalence, morbidity, and therapy of hepatitis E virus infection in pediatric renal allograft recipients. Pediatr. Nephrol. 2018, 33, 1215-1225. [CrossRef]

19. Wang, Y.; Chen, G.; Pan, Q.; Zhao, J. Chronic Hepatitis E in a Renal Transplant Recipient: The First Report of Genotype 4 Hepatitis E Virus Caused Chronic Infection in Organ Recipient. Gastroenterology 2018, 154, 1199-1201. [CrossRef]

20. Kurihara, T.; Yoshizumi, T.; Itoh, S.; Harimoto, N.; Harada, N.; Ikegami, T.; Inagaki, Y.; Oshiro, Y.; Ohkohchi, N.; Okamoto, H.; et al. Chronic hepatitis E virus infection after living donor liver transplantation via blood transfusion: A case report. Surg. Case Rep. 2016, 2, 32. [CrossRef]

21. Junge, N.; Pischke, S.; Baumann, U.; Goldschmidt, I.; Manns, M.; Wedemeyer, H.; Pfister, E.D. Results of single-center screening for chronic hepatitis $\mathrm{E}$ in children after liver transplantation and report on successful treatment with ribavirin. Pediatr. Transpl. 2013, 17, 343-347. [CrossRef]

22. Von Felden, J.; Alric, L.; Pischke, S.; Aitken, C.; Schlabe, S.; Spengler, U.; Giordani, M.T.; Schnitzler, P.; Bettinger, D.; Thimme, R.; et al. The burden of hepatitis E among patients with haematological malignancies: A retrospective European cohort study. J. Hepatol. 2019, 71, 465-472. [CrossRef]

23. McPherson, S.; Elsharkawy, A.M.; Ankcorn, M.; Ijaz, S.; Powell, J.; Rowe, I.; Tedder, R.; Andrews, P.A. Summary of the British Transplantation Society UK Guidelines for Hepatitis E and Solid Organ Transplantation. Transplantation 2018, 102, 15-20. [CrossRef] [PubMed]

24. Yoshida, T.; Takamura, M.; Goto, R.; Takeuchi, S.; Tsuchiya, A.; Kamimura, K.; Tasaki, M.; Nakagawa, Y.; Saito, K.; Tomita, Y.; et al. Efficacy and safety of ribavirin therapy for chronic hepatitis E after kidney transplantation. Hepatol. Res. 2019. [CrossRef] [PubMed]

25. Friebus-Kardash, J.; Eisenberger, U.; Ackermann, J.; Kribben, A.; Witzke, O.; Wenzel, J.; Rohn, H.; Fiedler, M. Prevalence of active hepatitis $\mathrm{E}$ virus infection and efficacy of ribavirin treatment in renal allograft recipients. Transpl. Infect. Dis. 2019, 21, e13088. [CrossRef] [PubMed]

26. Allaire, M.; Bazille, C.; Selves, J.; Salamé, E.; Altieri, M. Hepatitis E virus infection mimicking acute graft rejection in a liver transplant recipient. Clin. Res. Hepatol. Gastroenterol. 2018, 42, e68-e71. [CrossRef]

27. Antón, M.D.; Cuchillo, H.; Ferrando, I.; Moreno, N.; Kanter, J.; Roselló, E.; Moreno, E. Treatment with ribavirin of hepatitis E virus chronic infection in transplanted patients. Rev. Esp. Enferm. Dig. 2015, 107, 187-188.

28. Galante, A.; Pischke, S.; Polywka, S.; Luetgehethmann, M.; Suneetha, P.V.; Gisa, A.; Hiller, J.; Dienes, H.P.; Nashan, B.; Lohse, A.W.; et al. Relevance of chronic hepatitis E in liver transplant recipients: A real-life setting. Transpl. Infect. Dis. 2015, 17, 617-622. [CrossRef] 
29. Marion, O.; Abravanel, F.; Izopet, J.; Kamar, N. Failure to respond to ribavirin despite elevated intra-erythrocyte zinc level in transplant-patients with chronic hepatitis E virus infection. Transpl. Infect. Dis. 2019, 21, e13050. [CrossRef]

30. Low, E.X.S.; Tripon, E.; Lim, K.; Tan, P.S.; Low, H.C.; Dan, Y.Y.; Lee, Y.M.; Muthiah, M.; Loo, W.M.; Koh, C.J.; et al. Risk factors for ribavirin treatment failure in Asian organ transplant recipients with chronic hepatitis $\mathrm{E}$ infection. World J. Hepatol. 2019, 11, 553-561. [CrossRef]

31. Kamar, N.; Lhomme, S.; Abravanel, F.; Cointault, O.; Esposito, L.; Cardeau-Desangles, I.; Del Bello, A.; Dörr, G.; Lavayssière, L.; Nogier, M.B.; et al. An Early Viral Response Predicts the Virological Response to Ribavirin in Hepatitis E Virus Organ Transplant Patients. Transplantation 2015, 99, 2124-2131. [CrossRef]

32. Lens, S.; Mensa, L.; Gambato, M.; González, P.; Torras, X.; Soriano, G.; Costa, J.; Capón, A.; Londoño, M.C.; Mariño, Z.; et al. HEV infection in two referral centers in Spain: Epidemiology and clinical outcomes. J. Clin. Virol. 2015, 63, 76-80. [CrossRef]

33. Abravanel, F.; Lhomme, S.; Rostaing, L.; Kamar, N.; Izopet, J. Protracted fecal shedding of HEV during ribavirin therapy predicts treatment relapse. Clin. Infect. Dis. 2015, 60, 96-99. [CrossRef] [PubMed]

34. Choi, M.; Hofmann, J.; Köhler, A.; Wang, B.; Bock, C.T.; Schott, E.; Reinke, P.; Nickel, P. Prevalence and Clinical Correlates of Chronic Hepatitis E Infection in German Renal Transplant Recipients with Elevated Liver Enzymes. Transpl. Direct. 2018, 4, e341. [CrossRef] [PubMed]

35. Gruz, F.; Munné, M.S.; González, J.; Lizarraga Villagran, M.A.; Raffaele, P.P.; Descalzi, V.I. Ribavirin treatment of a patient with chronic hepatitis E. First case reported in Latin America. Acta Gastroenterol. Latinoam. 2016, $46,122-125$.

36. Mallet, V.; Sberro-Soussan, R.; Vallet-Pichard, A.; Roque-Afonso, A.M.; Pol, S. Transmission of Hepatitis E Virus by Plasma Exchange: A Case Report. Ann. Intern. Med. 2016, 164, 851-852. [CrossRef] [PubMed]

37. De Vries, M.A.; Samijn, J.P.; de Man, R.; Boots, J.M. Hepatitis E-associated encephalopathy in a renal transplant recipient. BMJ Case Rep. 2014, 2014. [CrossRef] [PubMed]

38. Klämbt, V.; Panning, M.; Seidl, M.; Häffner, K.; Pohl, M. Ribavirin therapy of hepatitis E infection may cause hyporegenerative anemia in pediatric renal transplant patients. Pediatr. Transpl. 2018, 22, e13195. [CrossRef] [PubMed]

39. Mallet, V.; Nicand, E.; Sultanik, P.; Chakvetadze, C.; Tessé, S.; Thervet, E.; Mouthon, L.; Sogni, P.; Pol, S. Brief communication: Case reports of ribavirin treatment for chronic hepatitis E. Ann. Intern. Med. 2010, 153, 85-89. [CrossRef]

40. Mainardi, V.; Gerona, S.; Ardao, G.; Ferreira, N.; Ramírez, G.; Arbiza, J.; Mirazo, S. Locally Acquired Chronic Hepatitis E Followed by Epstein-Barr Virus Reactivation and Burkitt Lymphoma as a Suspected Extrahepatic Manifestation in a Liver Transplant Recipient. Am. J. Case Rep. 2019, 20, 1016-1021. [CrossRef]

41. Carmo, J.; Marques, S.; Mateus, É.; Morbey, A.; Veloso, J.; Almeida-Santos, M.; Curran, M.; Barroso, E. Ribavirin for Chronic Hepatitis E in Liver-Transplant Setting: A Safe and Highly Effective Therapy. J. Clin. Gastroenterol. 2016, 50, 608. [CrossRef]

42. Tanaka, T.; Akamatsu, N.; Sakamoto, Y.; Inagaki, Y.; Oshiro, Y.; Ohkohchi, N.; Okamoto, H.; Kokudo, N. Treatment with ribavirin for chronic hepatitis $\mathrm{E}$ following living donor liver transplantation: A case report. Hepatol. Res. 2016, 46, 1058-1059. [CrossRef]

43. Speers, D.J.; Ma, M.X.; Faddy, H.M.; Nash, M.; Bowden, S.; de Boer, B.; MacNicholas, R.; MacQuillan, G.; Adams, L. Domestically acquired hepatitis E successfully treated with ribavirin in an Australian liver transplant recipient. Med. J. Aust. 2015, 202, 209-211. [CrossRef] [PubMed]

44. Klein, F.; Neuhaus, R.; Hofmann, J.; Rudolph, B.; Neuhaus, P.; Bahra, M. Successful Treatment of chronic Hepatitis E after an Orthotopic liver transplant with ribavirin monotherapy. Exp. Clin. Transplant. 2015, 13, 283-286. [PubMed]

45. Todesco, E.; Mazzola, A.; Akhavan, S.; Abravanel, F.; Poynard, T.; Roque-Afonso, A.M.; Peytavin, G.; Marcelin, A.G.; Calmus, Y.; Lecuyer, L.; et al. Chronic hepatitis E in a heart transplant patient: Sofosbuvir and ribavirin regimen not fully effective. Antivir. Ther. 2018, 23, 463-465. [CrossRef] [PubMed]

46. Belliere, J.; Abravanel, F.; Nogier, M.B.; Martinez, S.; Cintas, P.; Lhomme, S.; Lavayssière, L.; Cointault, O.; Faguer, S.; Izopet, J.; et al. Transfusion-acquired hepatitis E infection misdiagnosed as severe critical illness polyneuromyopathy in a heart transplant patient. Transpl. Infect. Dis. 2017, 19. [CrossRef] 
47. Nijskens, C.M.; Pas, S.D.; Cornelissen, J.; Caliskan, K.; Hoek, R.A.; Hesselink, D.A.; van der Eijk, A.A.; de Man, R.A. Hepatitis E virus genotype 3 infection in a tertiary referral center in the Netherlands: Clinical relevance and impact on patient morbidity. J. Clin. Virol. 2016, 74, 82-87. [CrossRef]

48. Pischke, S.; Stiefel, P.; Franz, B.; Bremer, B.; Suneetha, P.V.; Heim, A.; Ganzenmueller, T.; Schlue, J.; Horn-Wichmann, R.; Raupach, R.; et al. Chronic hepatitis e in heart transplant recipients. Am. J. Transpl. 2012, 12, 3128-3133. [CrossRef]

49. Chaillon, A.; Sirinelli, A.; De Muret, A.; Nicand, E.; d'Alteroche, L.; Goudeau, A. Sustained virologic response with ribavirin in chronic hepatitis E virus infection in heart transplantation. J. Heart Lung Transpl. 2011, 30, 841-843. [CrossRef]

50. Pischke, S.; Greer, M.; Hardtke, S.; Bremer, B.; Gisa, A.; Lehmann, P.; Haverich, A.; Welte, T.; Manns, M.P.; Wedemeyer, $\mathrm{H}$.; et al. Course and treatment of chronic hepatitis E virus infection in lung transplant recipients. Transpl. Infect. Dis. 2014, 16, 333-339. [CrossRef]

51. Riezebos-Brilman, A.; Puchhammer-Stöckl, E.; van der Weide, H.Y.; Haagsma, E.B.; Jaksch, P.; Bejvl, I.; Niesters, H.G.; Verschuuren, E.A. Chronic hepatitis E infection in lung transplant recipients. J. Heart Lung Transpl. 2013, 32, 341-346. [CrossRef]

52. Xhaard, A.; Roque-Afonso, A.M.; Mallet, V.; Ribaud, P.; Nguyen-Quoc, S.; Rohrlich, P.S.; Tabrizi, R.; Konopacki, J.; Lissandre, S.; Abravanel, F.; et al. Hepatitis E and Allogeneic Hematopoietic Stem Cell Transplantation: A French Nationwide SFGM-TC Retrospective Study. Viruses 2019, 11, 622. [CrossRef]

53. Lhomme, S.; Kamar, N.; Nicot, F.; Ducos, J.; Bismuth, M.; Garrigue, V.; Petitjean-Lecherbonnier, J.; Ollivier, I.; Alessandri-Gradt, E.; Goria, O.; et al. Mutation in the Hepatitis E Virus Polymerase and Outcome of Ribavirin Therapy. Antimicrob. Agents Chemother. 2015, 60, 1608-1614. [CrossRef] [PubMed]

54. Debing, Y.; Gisa, A.; Dallmeier, K.; Pischke, S.; Bremer, B.; Manns, M.; Neyts, J. A mutation in the hepatitis E virus RNA polymerase promotes its replication and associates with ribavirin treatment failure in organ transplant recipients. Gastroenterology 2014, 147, 1008-1011. [CrossRef] [PubMed]

55. Kamar, N.; Izopet, J.; Tripon, S.; Bismuth, M.; Hillaire, S.; Dumortier, J.; Radenne, S.; Coilly, A.; Garrigue, V.; D'Alteroche, L.; et al. Ribavirin for chronic hepatitis E virus infection in transplant recipients. N. Engl. J. Med. 2014, 370, 1111-1120. [CrossRef] [PubMed]

56. Lhomme, S.; DebRoy, S.; Kamar, N.; Abravanel, F.; Metsu, D.; Marion, O.; Dimeglio, C.; Cotler, S.J.; Izopet, J.; Dahari, H. Plasma Hepatitis E Virus Kinetics in Solid Organ Transplant Patients Receiving Ribavirin. Viruses 2019, 11, 630. [CrossRef]

57. Sridhar, S.; Chan, J.F.W.; Yap, D.Y.H.; Teng, J.L.L.; Huang, C.; Yip, C.C.Y.; Hung, I.F.N.; Tang, S.C.W.; Lau, S.K.P.; Woo, P.C.Y.; et al. Genotype 4 hepatitis E virus is a cause of chronic hepatitis in renal transplant recipients in Hong Kong. J. Viral Hepat. 2018, 25, 209-213. [CrossRef] [PubMed]

58. Sahli, R.; Fraga, M.; Semela, D.; Moradpour, D.; Gouttenoire, J. Rabbit HEV in immunosuppressed patients with hepatitis E acquired in Switzerland. J. Hepatol. 2019, 70, 1023-1025. [CrossRef]

59. Copegus (Ribavirin) Tables Label-FDA. Available online: https://www.accessdata.fda.gov/drugsatfda_docs/ label/2011/021511s023lbl.pdf (accessed on 26 December 2019).

60. Wu, X.; Dao Thi, V.L.; Liu, P.; Takacs, C.N.; Xiang, K.; Andrus, L.; Gouttenoire, J.; Moradpour, D.; Rice, C.M. Pan-Genotype Hepatitis E Virus Replication in Stem Cell-Derived Hepatocellular Systems. Gastroenterology 2018, 154, 663-674.e7. [CrossRef]

61. Drinane, M.; Jing Wang, X.; Watt, K. Sofosbuvir and Ribavirin Eradication of Refractory Hepatitis E in an Immunosuppressed Kidney Transplant Recipient. Hepatology 2019, 69, 2297-2299. [CrossRef]

62. Van der Valk, M.; Zaaijer, H.L.; Kater, A.P.; Schinkel, J. Sofosbuvir shows antiviral activity in a patient with chronic hepatitis E virus infection. J. Hepatol. 2017, 66, 242-243. [CrossRef]

63. Wahid, B. Successful treatment of HBV, HCV, \& HEV, with 12-week long use of tenofovir, sofosbuvir, daclatasvir, and ribavirin: A case report. J. Infect. Public Health 2019. [CrossRef]

64. Donnelly, M.C.; Imlach, S.N.; Abravanel, F.; Ramalingam, S.; Johannessen, I.; Petrik, J.; Fraser, A.R.; Campbell, J.D.; Bramley, P.; Dalton, H.R.; et al. Sofosbuvir and Daclatasvir Anti-Viral Therapy Fails to Clear HEV Viremia and Restore Reactive T Cells in a HEV/HCV Co-Infected Liver Transplant Recipient. Gastroenterology 2017, 152, 300-301. [CrossRef] [PubMed]

65. Schulz, M.; Papp, C.P.; Bock, C.T.; Hofmann, J.; Gerlach, U.A.; Maurer, M.M.; Eurich, D.; Mueller, T. Combination therapy of sofosbuvir and ribavirin fails to clear chronic hepatitis $\mathrm{E}$ infection in a multivisceral transplanted patient. J. Hepatol. 2019, 71, 225-227. [CrossRef] [PubMed] 
66. Cornberg, M.; Pischke, S.; Müller, T.; Behrendt, P.; Piecha, F.; Benckert, J.; Smith, A.; Koch, A.; Lohse, A.; Hardtke, S.; et al. Efficacy and safety of sofosbuvir monotherapy in patients with chronic hepatitis E-The HepNet SofE pilot study. J. Hepatol. 2019, 70, e129-e130. [CrossRef]

67. Van Wezel, E.M.; de Bruijne, J.; Damman, K.; Bijmolen, M.; van den Berg, A.P.; Verschuuren, E.A.M.; Ruigrok, G.A.; Riezebos-Brilman, A.; Knoester, M. Sofosbuvir Add-on to Ribavirin Treatment for Chronic Hepatitis E Virus Infection in Solid Organ Transplant Recipients Does Not Result in Sustained Virological Response. Open Forum Infect. Dis. 2019, 6, ofz346. [CrossRef] [PubMed]

68. Qu, C.; Li, Y.; Li, Y.; Yu, P.; Li, P.; Donkers, J.M.; van de Graaf, S.F.J.; de Man, R.A.; Peppelenbosch, M.P.; Pan, Q. FDA-drug screening identifies deptropine inhibiting hepatitis $\mathrm{E}$ virus involving the NF-KB-RIPK1-caspase axis. Antivir. Res. 2019, 170, 104588. [CrossRef] [PubMed]

69. Nishiyama, T.; Kobayashi, T.; Jirintai, S.; Kii, I.; Nagashima, S.; Prathiwi Primadharsini, P.; Nishizawa, T.; Okamoto, H. Screening of novel drugs for inhibiting hepatitis E virus replication. J. Virol. Methods 2019, 270,1-11. [CrossRef]

(C) 2019 by the authors. Licensee MDPI, Basel, Switzerland. This article is an open access article distributed under the terms and conditions of the Creative Commons Attribution (CC BY) license (http://creativecommons.org/licenses/by/4.0/). 